\title{
Concentration After the Nth Dose by Dose
}

National Cancer Institute

\section{Source}

National Cancer Institute. Concentration After the Nth Dose by Dose. NCI Thesaurus.

Code C92380.

The concentration at the Nth dose divided by the dose. 